\title{
The European Regional Integration in the IR Literature: A Review of Scholarly Support and Opposition
}

\author{
Agnes Katalin Koos \\ Political Science Department, Simon Fraser University, Vancouver, Canada. \\ Email: agnes_koos@sfu.ca \\ Received September 29 $9^{\text {th }}$, 2011; revised October 30 $0^{\text {th }}$, 2011; accepted November $9^{\text {th }}, 2011$.
}

\begin{abstract}
Most of what has been written on the ECSC/EEC/EC/EU, has not been done by international relations (IR) theorists, but by comparativists, sociologists, historians, anthropologists, legal scholars, and many others. These writings are in general classified as intergovernmentalist, federalist, and supranationalist (functionalist and neofunctionalist) in most accounts of the theoretical perspectives on the EU (Webb 1983, Rosamond 2000). Wiener and Diez 2004 add a rational choice institutional category, as well, as they think that the policy analysis within the polity developed into an autonomous brand of literature. It is only Andrew Hurrell in his chapter in Fawcett and Hurrell 1995, who makes an attempt to present the EU, as a regional integration, from the point of view of diverse IR approaches. Drawing on his classification scheme, I conduct an inquiry of the IR theories about European unification from the point of view of whether they allow for the iteration of the European experience in other parts of the world or not. The basic conclusion is that almost all IR work on Europe falls in the intergovernmentalist category, which tends to conceptualize the European Union as representing an $\mathbf{n}$ of 1 . (Intergovernmentalism is the choice of realism and neo-realism, English School, and neoliberal institutionalism.) Within the liberal IR paradigm, there is a tension between law-focused and security-focused approaches, on the one hand, and economic approaches, on the other. The first believe in the possibility of multiple integrations, while the latter does not think that they are desirable. Critical theories are also hindered by divergent normative commitments, though the class-based theorizing is very clear about pursuing the social control of markets.
\end{abstract}

Keywords: Regional Integration, Federalism, Supranationalism, Intergovernmentalism

"We are more and more Tuscans, Sicilians, Walloons and Welshmen, and less and less Italians, Frenchmen and Englishmen, or in other words we are becoming more and more Europeans." (Quoted in Keating 1989, p. 117)

\section{Introduction}

Many scholars from many social disciplines have become fascinated with Europe's post-WWII evolution. Their amazement has already produced a library-large literature, and an ever increasing number of institutions, centers, publications, and departments dedicated to European studies.

In contrast, if we look for the institutional infrastructure of regional integration studies, we are little likely to find anything beyond the United Nations University's Centre for Comparative Regional Integration Studies (UNU-CRIS). ${ }^{1}$

This imparity of institutionalized interest in the EU, on the one hand, and in regional integration, on the other, aptly contextualizes the question raised by ECSA in 1997 (Caporaso et al. 1997): "Does the European Union represent an n of 1?"

The answer involves more than purely methodological difficulties for researchers trying to apply quantitative methods on $n$ $=1$. If the European integration is a historically unique experience, it can be assumed to lead to one more state, even if a special one, such as multicultural and peacefully created, in the traditional world system of nation-states. Yet, if it is a specimen of a process that can be repeated in East Asia, Africa, and South America, for instance, then it is the herald of the demise of the Westphalian state system. The most influent theories of the international relations field, such as realism, the English School, neoliberal institutionalism, and even brands of constructivism,

${ }^{1}$ One of the rare exceptions is the Center for Comparative Integration Studies located in Denmark, at Aalborg University. are so deeply rooted in the assumption that the Westphalian state system is perennial, that a world composed of regional polities would refer them into history.

No wonder that the IR field manifested the least interest in and the least enthusiasm for the European project since its beginnings.

Most of what has been written on the ECSC/EEC/EC/EU, has not been done by IR theorists, but by comparativists, sociologists, historians, anthropologists, legal scholars, and so on. These writings are classified as intergovernmentalist, federalist, and supranationalist (functionalist or neofunctionalist) in most accounts of the theoretical perspectives on the EU (Webb 1983, Rosemond 2000). One newer volume on the issue, Wiener and Diez's (2004) European Integration Theory: Past, Present and Future, adds rational choice theory (RCT) institutionalism to the list, because in their vision the theories dealing with policies and politics have grown as important in "Europeanology" as the theories dealing with the polity itself_-or with the relationships among the member states.

In these accounts the approach called intergovernmentalist refers to the contribution of IR to the integration studies. Though there has not been a tendency to outline the approaches along disciplinary lines, in this case the paradigmatic boundary coincides with the IR field. In the intergovernmentalist approach the existence of separate sovereign states is encoded, with the corresponding skepticism about the outcome of the integration efforts. The question of whether there is a not Euroskeptic IR literature is very challenging, and little researched thus far.

Actually, it seems that the only author who ever wrote a review on this issue is Andrew Hurrell. In his chapter in the 1995 volume Regionalism in World Politics: Regional Organization and International Order (co-edited with Louise Fawcett), Hurrell classifies the IR theoretical perspectives on the EU, as a re- 
gional integration. ${ }^{2}$

Thus Hurrell thinks that 1) the European integration should be studied as a case of regionalism; and that 2) different IR theories have led to clearly distinguishable standpoints with regard to the study of regional integrations. Writing in 1995, he also noticed that work on regionalism was "relatively modest." I will extensively rely on the IR categories outlined by Hurrell, such as neorealism, neo-liberal institutionalism, constructivism, and domestic level theories. ${ }^{3}$ His work will serve as a kind of Ariadne thread, but, on the one hand, I will add a few new categories, and on the other, I make the reservation that the neo-functionalist approach cannot be uncontestably included in the IR literature. Though the functionalists made the most important prediction in the IR field for the last 70 years, functionalism has never been an IR paradigm. Its whole outlook is sociological. Mitrany and Deutsch successfully transplanted it in the political science field, bringing about something that can be taken for a holist alternative of the individualist liberal IR thinking. Haas is generally considered a neo-functionalist, who adopted a moderate stance on many issues dear to hard-core functionalists, such as the importance of public opinion (and of surveying it).

Notions of region, regionalism, and regionalization differ across the theoretical approaches to be presented. As a general feature, region has to be geographically demarcated, though the EU, for instance, resists attempts to fix its territorial boundaries. (And the ASEAN has also shown a growing pattern.) We may distinguish between sub-national micro-regions, cross-border regions, and regions above the nations-state, or macro-regions. In this paper I will confine to this latter meaning. In general, it is assumed that countries situated in the same geographical area may come closer to each other in both "spontaneous" and "politically driven" ways. "Spontaneously," the population of the respective countries increase their economic transactions with each other. Together with cultural exchanges, overlapping broadcasting, and tourism, the economic connectedness tends to homogenize the material and spiritual cultures, life styles, and mentalities. Actually, the phenomenon does not stop at the frontiers of the regions: this is what on the global scale is referred to as globalization. Yet, geographical proximity amplifies the spontaneous effects, and may trigger conscious political action to foster them. In some accounts, "regionalization" is reserved for the state-promoted integration only, in others, "regionalization" may be either spontaneous or state-promoted, and the term "regional integration" is used for the state promoted version. This is how I will apply the terms, when not explicitly referring to someone's divergent usage of them.

One more clarification should be made before introducing the authors. The same region may give rise to multiple regional integrations. In Europe, the EU has received most of the lime-

\footnotetext{
${ }^{2}$ And Hurrell has a more recent chapter in another book on the issue, in Farrell et al. 2005.

${ }^{3}$ As a referenced guide, Hurrell deserves that his classification scheme be presented before my alterations to it. He introduces three large categories with their sub-species. It is not difficult to liken his scheme to that of the realist Grieco (1990), who speaks about Realist, Neo-liberal institutionalist, and Liberal brands of thinking within the IR field. Hurrell's categories are: (a) Systemic theories: 1. Neo-realism (Waltz, Walt, Mearsheimer) and 2. Structural interdependence and globalization (Nye, Keohane, Sandholz \& Zysman). (b) Regionalism and interdependence: 1. Neo-functionalism (E.Haas K.Deutsch, Weiler), 2. Neo-liberal institutionalism (Keohane, Hoffmann, Moravcsik), and 3. Constructivism (Onuf, Adler, Wendt). (c) Domesticlevel theories: 1. Regionalism and state coherence (Charles Tripp), 2. Regime type and democratization (Doyle, Maoz, Russett, Burley), and 3. Convergence theories (when domestic policy preferences converge and states "lock in" them, as in Majone).
}

light, but there is also a European Security Area, represented by the Organisation for Security and Cooperation in Europe.

\section{Holist Theories on the IR Realist Side}

Hurrell labels his first large category "systemic theories," in the Waltzian sense. I believe that all systemic theories are holist, but not all holist theories, in the epistemological sense, are systemic theories in the Waltzian sense. ${ }^{4}$ Hurrell himself seems to also have been at a disarray of whether neo-liberal institutionalism is systemic enough to make the category of "systemic theories," or not, thus he shared Keohane's contribution between this category and the next. I will confine this section to realist authors, of whom Waltz, Walt, and Mearsheimer are specifically mentioned by Hurrell. And, I include the English School, particularly Hurrell himself.

\section{Structural (Neo-)Realism}

The Monnet-ian beginnings of the European integration are older than the Waltzian neorealist school in IR. The first IR realists commenting on the European Coal and Steel Community, and on the European Communities, were not expressly invoking the neo-realist theses, such as Grieco and Mearsheimer did later. The most well-known Euroskeptic of the 1960s was Stanley Hoffmann, who-however-is generally mentioned as the originator of the intergovernmentalist approach. Hoffmann was a realist, but the intergovernmentalist analysis took on some liberal traits later.

Hurrell does not think that in this area there were significant differences between pre-Waltzian and Waltzian standpoints. "Both classical realism and its more recent neo-realist variants stress the importance of external configurations of power. For the neo-realist, the politics of regionalism have much in common with the politics of alliance formation.” Or, in realism, alliances are little more than cheap talk. There is nothing really binding and nothing irreversible in them. For instance, in his 1988 paper, Grieco polemically refuses the possibility of cooperation among states, on grounds that their security concerns, thus concerns with the relative gains, override the temptation of absolute gains from a cooperation.

The moment when the neorealists dedicated a little more attention to the European integration came in the early 1990s. In a 1990 paper, Mearsheimer formulated the conclusions of the end of the Cold War for Europe. Since realists held that the European states were pushed into their "alliance" system by bipolarity, Mearsheimer 1990 predicted the end and reversal of the European developments. ${ }^{5}$

This prediction did not materialize. After the Single European Act in 1986, the Community went on the sign the Maastricht Treaty in 1992. In 1995, Grieco commented: "Now, from the vantage point of the mid-1990s, it is clear that the EC will not soon achieve the goals it set for itself in the Maastricht Treaty (p. 22). ${ }^{\circ 6}$ But the essence of this 1995 paper is to introduce some amendments to the structural realist theory that can explain the continuing integration. In a later paper, in 1996, the same amendment was used for a more specific task of explaining the European Monetary Union.

\footnotetext{
${ }^{4}$ Actually, Waltz's system is a very special case, in no other science a group formed by like units is studied as a system in its own right.

${ }^{5}$ "[W] [Would see the Europeans returning to their traditional concerns about relative gains and becoming less able to cooperate."

${ }^{6}$ Though in a footnote Grieco excuses his usage of "EC," instead of "EU" for the pre-Maastricht era of the polity, it sounds strange enough in a sentence in future tense! And his 1996 paper still uses "EC.”
} 
Grieco 1995 admits that “the Maastricht Treaty’s elements regarding EMU do indeed pose a serious challenge to neo-realist arguments about international institutions.” Thus he sets off "to show how neo-realism might be adapted in the face of the challenges raised by Maastricht in such a way as to respond to these problems in a productive manner." He presents a revised neo-realist argument dubbed "voice opportunities" thesis based on reasons of "secondary states" for cooperating with stronger partners through international institutions. Grieco claims that this argument is compatible with the hard core of the neo-realist research programme and is rooted in the thinking of Morgenthau. ${ }^{7}$ The hypothesis is that

"if states share a common interest and undertake negotiations on rules constituting a collaborative arrangement, then the weaker but still influential partners will seek to ensure that the rules so constructed will provide sufficient opportunities for them to voice their concerns and interests and thereby prevent or at least ameliorate their domination by stronger partners."

In the 1996 paper, this idea is concretized with France and Italy, economically weaker, but politically significant, choosing to cooperate with economically powerful Germany against Japan and maybe USA. Security and relative gain concerns are not mentioned, countries are supposed to pursue "mutual gain." The gains of the economically stronger partner are not detailed, and there are no guidelines of when the stronger partner will succumb to demands for institutionalization.

In the 1996 paper, Grieco is more tolerant toward non-systemic approaches to the international affairs than he was in 1988. He admits that unit-level analysts (such Sandholz and Zysman 1989), and functionalists (a composite category for "functional institutionalist” Keohane and neofunctionalists Haas and Schmitter) may also make valuable contributions to the study of the European integration. This paper of Grieco almost fits the description of Hurrell: "Neo-realism focuses attention both on powerpolitical pressures and on the dynamics of mercantilist economic competition."

Hurrell attributes lots of economic concerns to the neo-realist description to the European integration, such as the belief that "outside-in" economic pressures of mercantilist rivalry have continued to influence the path of European integration. For instance, that in the 1960s "de Gaulle placed great weight on European cooperation, as a means of countering le défi americain and later le défi japonais and so on. Yet, for hardcore neorealists, concerns with economy, with "low politics," could not compete with security reasons, they had, at maximum, some added role after the application of the primary explanatory factor, the role of the hegemon. Finally, Hurrell formulates two criticisms: "Neo-realism, however, says little about the character of regional cooperation once established and the ways in which the habits of sustained co-operation may involve institutional structures very different from the traditional idea of coalition. Neo-realism also says very little about the impact of domestic factors.”

\section{English School}

Hadley Bull shares the basic vision of anarchy with Waltz, but he takes more seriously the phenomenologically given fact that states do cooperate. It seems that the English School's understanding that anarchy is not necessarily Hobbesian comes from their larger emphasis on "low-level" interactions among

7“"[T]he idea that institutionalization has served as a post-war strategy by which France has sought to limit and channel German power was articulated in early post-war realist thinking about European economic cooperation, that is, in Hans Morgenthau's discussion of the [ECSC \& EC]”. states, mainly economic transactions, but also social exchange (migration, crossborder marriages and cultural contacts). And they also show a little more empathy toward the behavior of weak states, such as in Hurrell's claim on regionalization: “... many regionalist groupings are basically the natural response of weak states trapped in the world of strong." Neorealism neglects lesser states, and Grieco's amendment to the core doctrine targeted exactly this segment of "secondary state" behavior.

Yet, this idea of weak-state behavior has not gone farther than a few empathetic references and has not crystallized in an elaborated theory. In 2007, Hurrell admitted that:

"It has to be said that, as it developed, the English School was not especially attentive to regional and area studies. The emphasis was to be on the way in which things fit together, and on the study of international relations as a holistic and distinctive arena of social enquiry (p. 135)." Yet, in his account the whole of the IR field neglected the regional issue, and failed to integrate the expertise of area specialists. Hurrell thinks that this flows from the logic of IR, geared toward explaining with the global distribution of power, and more knowledge about regional balances of power, and regional aspects of the neomercantilist competition would be beneficial for the discipline.

In a paper published in 1996, Hurrell and Menon react to Simon Hix's 1994 proposal to study the EU as a polity, rather than as a group of states. ${ }^{8}$ Hurrell and Menon reject the suggestion, and intend to preserve the intergovernmental approach to the study of the EU: "Our argument, however, is that bargaining between states pervades the policy process in the EU and that such bargaining is subject to distinctive constraints that differ from those operating in 'normal' political systems."

Yet, they emphasize their distance from the "old" exclusivist intergovernmentalist approaches on grounds that not all statesystem centered perspectives are created equal. "It is not helpful to treat together older realist perspectives (such as Hoffmann writing in the 1960s) and the many recent varieties of liberal intergovernmentalism or institutionalism. Both accept that states are the central actors. Both believe that conflict, co-operation and integration are determined by the perceived interests of the major states. But realists and liberal institutionalists differ fundamentally on their assessment of the chances of sustained co-operation and on the role of Institutions. In particular, liberal intergovernmentalists have never viewed integration within the EC as strictly a zero-sum game.”

Hurrell and Menon's arguments against the strictest neorealist accounts are rooted in observations of state behavior, such as the possibility of sustained cooperation, the elasticity of the perception of state interest (which makes bargaining possible, and may also involve issue linkages), multi-level and multi-player games, the erosion of the monolithic character of the state, and "perhaps also ‥ new forms of identity." We may notice a shift in the interpretation of the state system, as well. The economic realm, mainly globalization and its impacts, is given more importance as compared to purely power distribution concerns, than by the neorealist accounts.

Of the co-authors of this paper, Menon seems to have gone into the direction of institutionalism later, while Hurrell came back to the problem of regionalization in 2007.

His main question is: "To what extent have these regional factors become more firmly established as important elements

\footnotetext{
${ }^{8} \mathrm{Hix} 1994$ claimed that "The EU now represents 'more than an" international organization", , and so 'theories of international politics are of limited use for studying the "internal” politics of the Community'." This being the case, the same theoretical approaches that are used to study national political systems may profitably be applied to the study of the EU.
} 
of the architecture of world politics, and to what extent are we living in an emerging multiregional system of international relations?”

And he basically answers that: "All regionalist arrangements have to be understood in relation to systemic or 'outside-in' factors-even if the most important condition for regionalism in a specific case is the relative weakness of such factors."

The region may be conceptualized as "the most appropriate and viable level to reconcile the changing and intensifying pressures of global capitalist competition on the one hand with the need for political regulation and management on the other." Yet, they have this value mainly for the "lesser states." During history, the behavior of lesser states has led to various international, global and regional initiatives. No explicit rules have been discovered in the behavior of these states, they may either balance or bandwagon, define variously the regions, choose different partners and different emphases of integration, such as more economic or more security-driven. It is worth to study the regional formations, as some may last. But all of the initiatives are subjected to the toleration of the great powers. For instance, the grand-scale Third World cooperation of the 1960s - 1970s, during which regionalization was subordinated to globalism, has eroded. Regionalism is easier tolerated by global power structures, which may be an explanation for the upsurge in regionalization in the 1990s. The success of the European integration has also invited emulation. But the degree of regionalization varies widely across regions, and there is no guarantee that any of them can repeat the European experience. Actually, Hurrell explicitly rejects the claim that regions are the "harbingers of change in the character of international society" on grounds that previous rounds of regionalism have receded, and because of "the strains besetting NAFTA, the fragility of Mercosur, ASEAN's difficulties in adjusting to a harsher regional environment, and the extremely limited results of regionalism in other parts of the world." Pragmatic realists tend to believe when they see. But when looking at a half-empty glass they tend to call it empty.

A last turn of the realist holist side is its collusion with social constructivism, as exemplified with the Copenhagen School. Barry Buzan started its contribution to the realist/English School literature by enlarging and dynamizing the notion of security (1983). In his account, military security is not the only one kind of security pursued by states, they are interested in political, economic, societal and ecological security, as well. The process of pursuing these goals is called "securitization." In publications coauthored with social constructivist Ole Waever, Buzan developed a comprehensive notion of societal security, while also relativised these concerns, moved far away from unique monolithic state security concepts, toward socially constructed issues, threats, and enemies.

In sum, within the realist holist approach, each regional integration is an idiosyncratic outcome of global and regional power distribution, and of general and specific economic challenges and pressures. In the case of the European integration, the geopolitical framework was the collapse of colonial empires, the rearrangement of the power rank-orders (with new powers emerging), and some threat from the part of the Soviet Union, counterbalanced by the US's Cold War strategy that pushed democracies in the same alliance system. There are no general rules of regionalization, neither can we claim that there is a viable general trend toward regionalization. All alliances are particular and reversible. The EU keeps being an $\mathrm{n}=1$.

\section{Holist Theories with Liberal Accents ${ }^{9}$}

This category is made of by four approaches, of which one is not commonly considered part of the IR literature. Yet, it is hard to speak about the field, and of its specific debates, without mentioning such a salient theoretical standpoint, on the basis of which the European integration got its start, and which keeps being the (phenomenologically, at least) most adequate description of what has happened in Europe.

\section{Functionalism and Neo-Functionalism}

Functionalism in political science is mainly associated with the name of David Mitrany and Karl Deutsch, while its version neofunctionalism can be exemplified with Ernst Haas and Schmitter. Haas 1964 sums up the functionalist creed, and presents his own amendments to it. The functionalist theses pertinent to integration are: 0 . The first mover in human affairs is people's desire for more welfare. 1 . States are responsible for assuring human fulfillment. ${ }^{10} 2$. The sphere of politics, focused on power, should be separated from the technical sphere where welfare issues are treated. 3. Expects that "science would push back the boundary of power," in the sense that science will be able to show up increasingly more common interests, while harmonizing the divergent ones, e.g. in disarmament issues. 4. Peace is not static, keeping peoples apart, but active, a "social peace," on the basis of solved conflicts. 5. Human beings can and do maintain multiple identities; new functions create new loyalties. 6. Federalism may come in installments. ${ }^{11} 7$. Function precedes form. 8. Functional spillovers (+spill-backs, spill-arounds) are the mechanisms through which the integration processes maintain and fuel further integration.

Haas adopts a critical stance toward some traits of classic functionalism, such as its teleology (explanations with functions, rather than with causes), and separation of power and welfare, but he is critical against realism, as well, claiming that the Realist system, based on balancing, has never existed. He elaborates on possibilities of bringing about "beyond-state" organizations that will effectively command people's loyalties instead of the nation-state. Personal political loyalties are the result of satisfaction with the performance of an agency. A gradual transfer of loyalties to international organizations performing important functions is likely. And spillovers may also work: integrative lessons learned in one functional context will be applied in others, and learning may redefine earlier concepttions of self-interest.

Haas does not think expressly in terms of regional integrations: in his 1964 book, he analyzes the activity of the International Labor Organization. But he generalizes to the possibilities of international organizations of any kind. ${ }^{12}$ He thinks that "there will be a continued drift toward supranationality," but not with planning (as Gunnar Myrdal imagined, for instance).

\footnotetext{
${ }^{9}$ Hurrell's term for a similar category is “(b) Regionalism and interdependence.”

${ }^{10}$ This collides with the realist claim that state behavior is not subject to moral judgment. Also involves that when states cannot assure human fulfillment within their competence, they are obliged to delegate sovereignty to other forums.

${ }^{11}$ Mitrany is attributed the opinion that there won't be need of accomplished political union in Europe or in any region, the regional integrations won't lead to new "Westphalian" states.

${ }^{12}$ Haas 1958 defines integration as the process "whereby political actors in several, distinct national settings are persuaded to shift their loyalties, expectations and political activities toward a new centre, whose institutions process or demand jurisdiction over the pre-existing national states.” Haas 1976 defines integration as institutionalized procedures devised by governments for coping with the condition of interdependence, where "coping" may take
} 
In a contingent, ad hoc way, under the double influence of the international systemic forces and the domestic forces. The systemic forces include economic tensions, and the individual societies do not develop independently of each other. In 1976, following the Eurosklerosis of the 1970s, Haas rearticulated his skeptical amendments to the enthusiastic classic functionalist theory, but also made a convincing argument about the decision styles within the EC, claiming that in the old issue areas the integration has not been halted, let alone reversed.

In sum, neo-functionalism maintained the basic functionalist thesis that the world is moving away from the anarchic state system, towards various supranational institutions. Haas opened much more room for contingence than the old functionalists. If Mitrany or Deutsch can be credited with the belief the European experience is not unique, we may hesitate to accord the same view to Haas. While he allows for the fact that there are forces and potentialities to fuel integration everywhere, neofunctionalism makes the actualization of these impulses dependent on too many circumstances, and they may be even defeated by "turbulences." The more skeptic account seems to be related to the fact that in the neorealist version, the integration is elitedriven rather than really popular.

\section{Neo-Liberal Institutionalism}

The most influent and most seriously taken critique of neorealism within the mainstream IR literature reproaches the Waltzians' neglect of economic interdependence (which later started to be referred to as globalization). The increasing economic interdependence affects state capacities, the real or perceived interests of the states, and their incentives for interaction in the international arena (such as cooperating, balancing, bandwagoning, isolating themselves, or resorting to aggression). While it is intuitively clear that interdependence creates the need for beyond-state action-both for regulating the moves of transnational actors and for handling the transnational consequences of modern production systems - there is no straight causal line from deepening globalization to the advancement of regional integrations. For the supporters of international cooperation, the regional integrations have their competitors in bilateral agreements, issue-based IGOs, international regimes, and world gornance, while for hard-liner realists, the low politics of economics won't ever make its way into the high politics.

Keohane and Nye (1977) argued that countries thrown in the situation of interdependence, mainly those with asymmetrical interdependences, suffer from sensitivity and vulnerability to international developments. To a certain extent, states try to defend themselves with purposive actions, among which cooperation is by far the most effective. Cooperative behavior is associated with international regimes, and is endogenous with international institutions. The shared vision of the authors is a world where

- societies are connected by multiple channels,

- states are not the only actors in the international arena,

- there is not a clear primacy of security issues versus economy (high politics does not always constrain low politics), and

- there are limits on the (meaningfulness of) use of military force.

Yet, the two authors' separate work suggests that they have had, in fact, slightly divergent cognitive frames for the problematic of interdependence. Keohane relies on rational choice explanations, while Nye is more inclined toward functionalist-like accounts.

Nye wrote extensively on regionalization at the end of the 1960s, and in 1971 published a book entitled Peace in parts:
Integration and conflict in regional organization, a comparative study of regional evolution around the globe. The macroregion, in which Nye is interested, is "a limited number of states linked together by a geographical relationship and by a degree of mutual interdependence.” Interdependence can be regulated by means of deliberate state policies, and Nye's description of "package deals" pushing forward the integration comes close to the functionalist notion of spillover (for instance, in Sandholtz and Zysman's 1992 account).

Maybe the most notable feature of the book is its effort to typify regional integrations and measure their development. Nye 1968 has already distinguished three aspects of integration: economic, social (leading to a "transnational society,") and political. Political interdependence means, on the one hand, policy harmonization, and on the other, the emergence of a "security community" in Deutsch's sense (when the peoples involved find increasingly unthinkable to wage war against each other). Both the involvement of three interrelated areas of social existence, and the efforts to work out measures of integration, fall in the very functionalist tradition. Nye clearly aimed at an approach to the European integration that did not suppose it was an $\mathrm{n}=1$. Yet, at the end of the day, Nye lost much of his confidence that the available conceptual tools can get to the essence of the phenomena:

"Ten years after the formation of the EEC we are faced with a more difficult beast to analyze than many people expected at that time. Instead of a classical federation or neat 'supranational' authority we have a complex web of interdependences between strengthened nation-states. With the nature of the beast likely to remain ambiguous we need more refined concepts and measurements. At the same time we are faced with regional integration schemes in less developed areas which appear at times to resemble the European animal but in causal terms may turn out to be of different genus or species."

Keohane's 1984 book endorses the realist axiom that states are unitary, rational actors. But they are able of cooperation, at least their cooperative relationships, once implemented, may outlast the hegemon who introduced them. In favorable conditions, states may embark on a virtuous course of cooperation ${ }^{13}$ even in the absence of hegemonic pressures (but not against it). Such favorable conditions are, for instance, when the "game" is Stag Hunt rather than Prisoners' Dilemma, when issue linkages are possible, and when efficient institutions can be set up to facilitate information exchange, monitor compliance, and punish the defectors. Keohane's vision does not allow for regional integrations going beyond intergovernmental arrangements: "International regimes should not be interpreted as elements of a new international order 'beyond the nation-state.' They should be comprehended chiefly as arrangements motivated by selfinterest: as components of systems in which sovereignty remains a constitutive principle," further, which "will be shaped by their most powerful members."

Keohane's overall outlook suggests that institutions, unlike realism's alliances, are here to last. They do not go deep, but successful cooperation over decades may build up some solidarity among participants. We do not get clear clues from Keohane about where, and when can we expect the emergence of an international regime, or an IGO, or a regional integration.

When Keohane wrote more concretely on the European integration, he endorsed the intergovernmentalist approach, as in the volume that he co-edited with Stanley Hoffmann in $1991 .^{14}$

\footnotetext{
${ }^{13}$ Keohane defines cooperation as mutual policy adjustment to reduce harm to other states.

${ }^{14}$ The volume contains Moravcsik's "Negotiating the Single European Act," as well.
} 
Keohane and Hoffmann wrote a common Introduction to the book, in which they proposed three theses about European institutions: " 1 . The EC is best characterized as neither an international regime nor an emerging state but as a network involving the pooling of sovereignty. 2. The political process of the EC is well described by the term "supranationality" as used by Ernst Haas $^{15}$. 3. However, the EC has always rested on a set of intergovernmental bargains, and the Single European Act is no exception to this generalization. (p. 10)" Though the neo-functionalist term "supranationality" is rehabilitated, the spillover is mostly rejected on behalf of the creed that "large-scale social change is typically the result of conjunction of events that are not tightly related to each other." The contingency of the European trajectory enters mainly through its intergovernmentalist element. (Whether the states' interests will cohere or their perception of their interests will do, what is called the preference-convergence hypothesis, is a matter of caprices of history). The authors think that the EC will keep in place, but they are skeptical about its furthering (either deepening or enlargement).

Before turning to the intergovernmentalist brand, I would mention Sandholtz and Zysman's 1989 paper, written three years before the Maastricht Treaty, in which the authors try to give an account of why the integration seems to proceed. Their approach is peculiar enough, a mixture of neoliberal institutionalist arguments on economic interdependence with realist arguments on security issues (toward the end of the Cold War, recasting Europe's the security bargain with the US), and with liberal arguments on sub-national entities, which here are the domestic elites. "We therefore propose to analyze 1992 in terms of elite bargains formulated in response to international structural change and the Commission's policy entrepreneurship.” Sandholtz and Zysman cannot avoid the same problem of contingency that characterizes Keohane and Hoffmann's intergovernmental bargains proposal. On the contrary, their explanation gets messier and less convincing because of the arbitrariness of definition of various national business elites.

\section{Intergovernmentalism}

Intergovernmentalist approach, as a distinct paradigm, is most visible from other disciplines, not from the IR field. This is how a sociologist, a comparativist, or a legal scholar working in the European studies field, would classify the EU-related work of an IR scholar belonging to the realist, English School, or neoliberal institutionalist tradition. In addition, even some IR liberals have an intergovernmentalist basic stance towards the European integration. More closely, intergovernmentalism is associated with the name of Stanley Hoffmann (the "old" intergovernmentalism) and of Andrew Moravcsik (the "liberal" intergovernmentalism).

The technical meaning of intergovernmentalism is that power remains with the member-states and decisions are to be made in unanimity - the rules of majoritarian decision-making do not apply. ${ }^{16}$ Applied to the European integration, Hoffmann suggests that national governments control the level and speed of European integration. Governmental decisions are based on transient domestic political and economic issues, infusing such a contin-

\footnotetext{
$\overline{{ }^{15} \text { This meaning of supranationality is not federalism, but rather Puchala's }}$ concordance system and Gary Marks's multi-level governance. In Keohane's and Hoffmann's interpretation it echoes Keohane's definition for cooperation/collective action, that states mutually adjust their policies to reduce harm to each other and pursue collective gains.

${ }^{16}$ Symmetrically, supranationalism can be defined as an alternative method of decision-making, allowing for the possibility that other states' decisions become compulsory within a member state.
}

gency to the European evolution which excludes all functionalist idea about necessary spillovers. Hoffmann 1966 criticizes neofunctionalists on many accounts, such as 1) regional integration is not a self-contained process, it is subject to the external constraints of the international system, in this case the context of Cold War and US hegemony; 2) states are uniquely powerful actors; and 3) functionalists fail to distinguish between low and high politics. Yet, Hoffmann cannot give a coherent account of why states adopt a certain issue position at all-thus he cannot ground their opposition to other states' suggestions or to the Commissions's suggestion, either.

Moravcsik tries to fill in this gap of intergovernmentalist theorization, and he turns to domestic preference-building mechanisms to explain state positions on different issues. In this sense he is a liberal. He tries to systematize predictions about state behavior: "I argue that a tripartite explanation of integrationeconomic interest, relative power, credible commitments-accounts for the form, substance, and timing of major steps toward European integration (p. 4)." Yet, at a closer view, his account of "economic interest," for instance, falls apart to attributions of economic creeds to groups of decision-makers across countries. As Helen Wallace pointed out, ${ }^{17}$ the economic doctrines in which the negotiators framed their national interests changed a lot during the decades. Moravcsik tends to attribute the theory that most fits his explanation to the actors. And Wallace also suggests that Moravcsik's analysis "provides formidable arguments against those who portray European integration as necessarily a cumulative and irreversible process," an accusation vehemently denied by Moravcsik. Yet, his analyses 1) fail to ground the irreversibility of the process; 2) fail to ground the generalizability of the process, 3) fail to give a good description of the everyday workings of the integration process. This latest argument was formulated by institutionalist and comparativist critics, such as Garrett and Tsebelis 1996, Wincott 1995, and Mattli 1999, who also made some epistemological remarks about the selection biases inherent to Moravcsik's methodology, and the non-testability of his proposals.

To the direct question of ECSA Review, Moravcsik answered that yes, the EU was an $\mathrm{n}=1$, but this was not a reason for despair. "The ' $n=1$ problem' is not unique to the EU; it is a foundational characteristic of social science. Unlike collisions among elementary particles, complex social interactions are in fundamental ways unique. Yet useful theories and results in international and comparative politics exist because scholars have circumvented the $\mathrm{n}=1$ problem by employing [various] methods." Unfortunately, writing about the genesis of an $\mathrm{n}=1$ is an exercise in description, rather than an explanation.

\section{Constructivism}

Beginning with the 1980s, a new paradigm made its entrance into the IR field. While the already established realist, liberal, and neoliberal institutionalist approaches promoted capabilities, interests, and rationality as explanatory principles, the new approach, constructivism, claimed that none of these factors can work without shared understandings about what is a resource to be sought, what is an interest to be defended, and what is a rational course of actions. Constructivism is sometimes portrayed as if it would explain with ideas and identities. More accurately, it is a meta-theory about the social construction of meanings necessary for real-world behavior, which was developed within sociology, and affected IR in various ways.

First, constructivism is an ingredient of the functionalist and

\footnotetext{
${ }^{17}$ At the symposium organized to discuss Moravcsik’s 1998 book.
} 
neo-functionalist integration theories. Mitrany and Deutsch expected denser transnational interactions carried out under the control of successful international organizations to build up "a sense of community, 'we-ness,' mutual sympathy, loyalty, and shared identity. This in turn is likely to be based on shared principles, on collectively held norms, and on common understandings." 18 Though these views have underlain the whole of the EU construction within the supranationalist and federalist approaches, they did not emerge in the IR literature until the strengthening of a so-called "social constructivist" paradigm in the 1990s.

Second, I would mention a group of theorists, who, such as Adler, Katzenstein, and Wendt, applied constructivist principles to explain state behavior and the inter-state system. Adler and Barnett's 1998 edited volume also refers to Deutsch, ${ }^{19}$ this time to his concept of "security community." Deutsch thought that security communities may be either amalgamated (when the countries unify: "formally merge" and bring about some kind of common government) or pluralistic (when states preserve their sovereignty). The book sets out to explore the possibilities of pluralistic security communities, in which there is no sovereignty transfer, thus no valid comparison with the European integration can be made.

In a similar vein, Wendt 1994 gives a programmatic formulation of explanations of peaceful coexistence without sovereignty transfer. "Constructivism is a structural theory of the international system that makes the following core claims: 1) states are the principal units of analysis for international political theory; 2) the key structures in the states system are intersubjective, rather than material; and 3) state identities and interests are in important part constructed by these social structures, rather than given exogenously to the system by human nature or domestic politics. The second claim opposes realism. The third opposes systemic theories that are rationalist in form ..." Wendt thinks that the constructivist axioms allow for an international system in which states remain the major (if not unique) players, but systemic change becomes possible: "It is widely thought that state-centric systemic international relations theory cannot explain structural change and so ought to be abandoned. In my view, the problem lies not with statism but with two other commitments that inform contemporary understandings of structural theory: realism and rationalism.”

Thus Wendt proposes an idealist statism to account for change in the system, but he confesses not having any clear prediction about how the world would or should evolve. "I specifically do not impute any directionality or teleology to the historical process." His theoretical foundation does not allow for the formation of supranational power centers, least for their taking the form of regional integrations, and does not provide reasons for which the accidental emergence of a regional integration in one part of the world should be repeated in other parts of the inter-state system.

John Ruggie's work on international regimes, and of Nicholas Onuf's on agent-structure problems are other well established versions of constructivism in IR. Yet, pertinent to the European integration, it is the so-called Copenhagen School's activity that should be mentioned.

In 1999, Moravcsik harshly criticized their contribution to the integration literature. He summed up the constructivist group's basic outlook in two propositions. "The first is that governmental élites choose specific policies, policy ideas, strategies, and concrete interests because they (or their justifications) are

\footnotetext{
${ }^{18}$ Deutsch is quoted in Hurrell p. 65.

${ }^{19}$ In the editors' introductory chapter, entitled "Security communities in theoretical perspective.”
}

consistent with more general, deeper, collectively held ideas or discourses. The second core proposition shared by nearly all participants in this volume states that underlying ideas and discourses change only at rare 'critical junctures,' which arise in response to political crises.” Moravcsik thinks that the first claim is unacceptable, while the second is not new: it is part of rational accounts, as well, as of his liberal intergovernmentalism. Yet, it seems that the boundaries of the group are far from sharp. Ole Waever is a founding member, but was Moravcsik right when he listed Ben Rosamond, Martin Marcussen, Thomas Risse, Jeffrey Checkel and Thomas Diez in the same group? In their rejoinder, Risse and Wiener 1999 point out significant differences among these authors. And they claim that Moravcsik misunderstands social constructivism. "Rationalist accounts including liberal intergovernmentalism bracket and exogenize ... interests and identities, while constructivism tries to bring them into the light of investigation.”

Finally, in the field of constructivist theories, the American/British exclusivity is not as pervasive as in the previously mentioned approaches. The Copenhagen School is geographically Europe-based, and the members of the social constructivist group have strong ties with the old continent. In addition, the Asian region has also found a recognized theorist in the person of Amirav Acharya. In his 2003 paper, Acharya makes a very welcome comparison between European and East Asian regionalism:

"Asian institutions have not taken the supranational path of the European Union. Instead, they have been sovereignty conforming. The EU emerged because the nation-state was blamed for two major catastrophic wars. Asian norms and institutions were shaped by decolonization at a time when the main concern of regional actors was to preserve the modern nation-state as a permanent feature of the Asian political order. The reason why Asia has had no European-style institutions has a lot do with the norms of sovereignty developed in the early aftermath of World War II. At the conference of Asian and African states held in Bandung, Indonesia, in 1955, a decision was taken not to bureaucratize regional cooperation because it might undermine the hard-earned sovereignty of the new states. The 'basic aim' of that conference was 'the formulation and establishment of certain norms for the conduct of present-day international relations and the instruments for the practical application of these norms.”

To large extents, Asian regionalism relies on informal rules, shared norms, and consensus-building, non-confrontational bargaining style. The argument of Acharya is that these have been effective thus far, ${ }^{20}$ and will be in the future, as well. "Instead of sliding into anarchy or organizing itself into a pre-Westphalian hierarchy, Asia is increasingly able to manage its insecurity through shared regional norms, rising economic interdependence, and growing institutional linkages: precisely the kind of mechanisms that the 'ripe for rivalry' thesis underestimates." The question is whether the rising economic interdependence, and growing institutional linkages will or will not induce the same type of evolution toward supranationality: precisely as in Europe. And if Acharya was right in 1997 that the ASEAN Way is characterized by pragmatism and expediency rather than by dogmatic clinging on organizational principles, then we may expect the Asian states to embark on an "ever closer union" course, as well.

In sum, constructivism is too fragmented to distill a unique

\footnotetext{
${ }^{20}$ And he quotes Barry Buzan and Gerald Segal who acknowledged that "The Association of South-east Asian Nations (ASEAN) states have constructed a durable security regime that has allowed them to solve and demilitarise a variety of disputes between them.”
} 
position with regard to their take on Europe is $n=1$. I would suggest that statist constructivism is more reluctant to allow for the iteration of the European experience than societal constructivisms, which are interested in the identities of people rather than of states.

\section{Individualist Theories}

\section{Liberalism}

IR realism, and Hurrell too, classifies theories as either structural or domestic, the latter term clearly embodying a statist standpoint. From a more general epistemological viewpoint, the liberal IR theory, which is the only one specimen of the "domestic" category, can be called "individualist."

Liberalism has a long tradition in the field of international thinking, but it did not cohere into a salient paradigm at parity with realism until the 1990s. It was Doyle who made a first attempt to systematize liberal beliefs in 1986, and the direct heir of this attempt is Russett and Oneal's 2001 book on "Triangulating peace," that is, on Kantian peace. This synthesis is the best summary of the substantive theses of IR liberalism (or liberalism's in the IR field). Similarly, Moravcsik 1997 gives an account of IR liberalism that epistemologically parallels the “axioms" of IR realism:

1) Agency - The fundamental actors in international politics are individuals and private groups, who exchange and may organize (collective action) to promote their interests.

2) Representation and State Preferences-States (or other political institutions) represent some subset of domestic society, whose interests the rational state officials pursue through world politics.

3) Interdependence and the International System-The configuration of interdependent state preferences determines state behavior. Each state seeks to realize its distinctive preferences under varying constraints imposed by the preferences of other states.

Other accounts try to get the big picture, and include features of the liberal tradition which are beyond the realists-endorsed IR issues, such as development, welfare aims, and values. For instance, Zacher and Matthew (1992) think that the core theses of liberalism are the following:

1) International relations are gradually being transformed so that they promote greater human freedom and establishing conditions of peace, prosperity and justice. (Progressive, meliorist stance, but without a necessary end-state).

2) Central to the realization of greater human freedom is the growth of international cooperation.

3) International relations are being transformed by a process of modernization, unleashed by the scientific revolution.

Liberal thinkers often earned the label of idealist and utopian because of their open engagement with moral assessments and normative choices. Yet, from the perspective of outsiders, realism is not axiologically neutral, either. It confers moral value on the maintenance of nation-states, and the furthering of what is perceived as national interest, otherwise, enshrines state sovereignty and nationalism. Thus the difference between liberalism and realism lies in what kinds of values they defend, rather than in one being engaged and the other value-free. The liberals' basic individualism is reasonably compatible with a human rights framework that sets limits to state sovereignty. From this perspective, nation-states are accidental formations, which may or may not be the frames that best serve the cause of human rights and human welfare. This way of reasoning meets the functionalists' claim that states are responsible for the welfare of their citizens.

Functionalism is a holist paradigm, while liberalism is basically individualist, but their shared moral outlook and the resilience of individualism has brought them in the same camp with regard to the possibility of international cooperation. ${ }^{21}$ Liberals of all brands allow for the real-world causal consequences of international organizations, including regional integrations.

The real hard-core liberal IR theory is geared toward admitting the possibility of international institutions and international law able to achieve the compliance of states. In 1993, Anne-Marie Slaughter Burley contributed to two papers ${ }^{22}$ analyzing how compliance with the international law may be achieved, for instance by embedding the international agreements in domestic political and bureaucratic processes. She has also found evidence for the Kantian relationship between democracy and effectiveness of international law.

From this legal perspective, the sectoral nature of the organization/integration is not really relevant. Yet, the literature on regional integrations has actually become split along sectoral lines. There is, on the one hand, a literature of the economic regionalism, and, on the other, of the security regimes. For both, the EU is a par excellence specimen, but only one case of several possible.

Liberal economists are not as enthusiastic about regional economic integrations as other liberal theorists are when they spot a well functioning group of states. Some of them (e.g. Paul Krugman and Larry Summers) argue that regional preferential agreements work against global free trade, and may induce competition and conflict among regions. According to Mansfied and Milner 1999, the evidence is shared with regard to the malignancy of the new wave of regionalization in the 1990s. In general, economic modeling shows a decrease of the overall freedom of trade when regional integrations are established, while empirical studies show, that "regionalism can, depending on the circumstances, be associated with either more or less general liberalization.' ' In their 1999 article, Mansfied and Milner do not try to introduce other economic criteria for assessing regional economic integrations, than the freedom-of-trade considerations. ${ }^{23}$ In the political domain, the authors are interested in whether regional arrangements serve as vehicles for the interests of the most powerful states, and find that "in contrast to the interwar period, there is relatively little indication that regionalism has been the product of active attempts by states to promote their political-military power."

Another "specialized" perspective on regional integrations is security-focused. It seems that this liberal version of security studies is more European than American. Charillon 2005 claims that "the regionalization of security issues is a growing trend," and Tavares 2008 concurs that "important aspects of international politics tend to be regional rather than fully global or exclusively national-some regions peaceful, others are violent.” Drawing on Buzan and Waever 2003, and on Lake and Morgan 1997, Tavares suggests a theory built around the notion of regional peace and security cluster. These clusters operate at

\footnotetext{
${ }^{21}$ Yet, in economy, for instance, liberalism won't relinquish its individualism. ${ }^{22}$ Slaughter Burley 1993 and Burley and Mattli 1993.

${ }^{23}$ Yet, their historical account suggests that states may have various reasons for joining a regional bloc, such as fostering industrialization: "Unlike the episode of the 1930s, the current initiatives represent efforts to facilitate their members' participation in the world economy rather than their withdrawal from it. Unlike those in the 1950s and 1960s, the initiatives involving developing countries are part of a strategy to liberalize and open their economies to implement export- and foreign investment-led policies rather than to promote import substitution.”
} 
various levels of regional integration, the third level of "regional community" having been achieved by the EU only. It is to be mentioned, that, as in Buzan and Waever 2003 too, economic, social and domestic political features have a role in the nature of security clusters.

And finally, we have the questions originated in comparative politics studies, about how an integration of (originally) sovereign states can be governed? One of the earliest answers was Puchala's 1972 description of the EU as a "Concordance System," which "includes actors from subnational, national, transnational and supranational levels, without a clear or pre-established hierarchy among them. It is international, but rather bureaucratic than intergovernmental." This vision matured in the theory of the multi-level governance later, regularly associated with the name of Gary Marks and Liesbeth Hooghe.

While the theory of multi-level governance is not regarded as part of the IR literature, a rival theory of the regulatory state is listed among IR theories by Hurrell (as "convergence theories”). Probably because in this vision forwarded by Majone, the technocratic center won't ever materialize as a power-center able to extract money and impose compliance. It gets only rulemaking attributions from the member states, in order to formulate policies on which these latter already converge. Majone does not exclude the possibility that similar regulatory convergences aided by institutions may emerge anywhere on the globe.

Yet, governance theorists are unlikely to be taken seriously in the IR field unless give an account of what happens to state sovereignty when supranationalism emerges. One answer is the pooling of sovereignty, which may lead to either a regulatory center, or to a thicker supranational forum, as the EU is supposed to be. Another explanation (Mattli 2000) relies on the concept of "sovereignty bargains." The term was coined by Karen Litfin in 1997. "States engage in sovereignty bargains in which they voluntarily accept some limitations in exchange for certain benefits." In this perspective, the monolithic principle of sovereignty falls apart into three dimensions: autonomy, control, and legitimacy. ${ }^{24}$ "In a sovereignty bargain, control may be enhanced by sacrificing autonomy; or increased control may undercut a state's legitimacy. While sovereignty bargains reconfigure sovereignty, they do not necessarily diminish it; reduced autonomy, for example, may be the price to pay for enhanced control or legitimacy.” This way IR liberalism tries to live up to Moravcsik's warnings that integration will be acceptable to states only as long as "it strengthens, rather than weakens, their control over domestic affairs, permitting them to attain goals otherwise unachievable."

In sum, the IR liberals are basically optimistic about the possibility of regional integrations, and think about them in plural. The drawback is that 1) they are not particularly supportive of regional economic integrations, and 2) their accounts about regionalization do not come together in one comprehensive narrative such as the functionalist.

\section{Critical Theories}

The category of critical theories, completely missing from Hurrell's account, is introduced for perspectives that are not contented with giving an account of the international arena, but have the ambition to induce changes in it.

Looking at the previous categories, there are two visions that give an account of how regional integration is possible and

\footnotetext{
24،Autonomy refers to independence in policymaking and action; control is the ability to produce an effect; and legitimacy refers to the recognized right to make rules.” Legitimacy may be internal and external.
}

allow for their development. ${ }^{25}$ A core liberal theory suggests that democratic trading countries bring about an international law that at its turn fuses with the domestic laws, and lays the foundations for state integrations of any kind, issue-based, regional, and global. Yet, this brand of liberalism, the Kantian peace theory does not elaborate on the propelling forces of the democratic peace(ful integration). Functionalism has elaborated on the causes (people desire of more welfare) and mechanisms (spillovers and loyalty shifts) of issue-based or regional integrations. This account is highly relevant for what happened in Europe, but has two built-in limitations:

1) Assumes that states start from economic cooperation, which is applicable to industrial and post-industrial countries only. For pre-industrial countries in Africa, unifying markets is not the hottest item on agenda. They would probably start from the security side.

2) It is a "peace in parts," an incremental account, both in time and geographically (or along issues). As Mansfield and Milner pointed out, in economy, the regional preferential agreements may come to the detriment of overall freedom of trade, and a group of states getting stronger in virtue of their regional integration may impose its political will on looser organized third parties.

In addition, in the 70 years since the formulation of the functionalist integration theory, the world underwent changes that ask for amendments to the theory. As pressed by realists, the problem of international terrorism should be addressed. Functionalism is blind to polarity issues, and cannot conceptualize the EU in the role of the first challenger of a declining, but still powerful hegemon that thinks about its own position in IR realist terms. Though economic interdependence among the participant countries is among the assumptions of functionalism, it cannot handle the issue of globalization, as such: the interdependence among all countries of the world. Actually, some components of globalization, as the formation of a common material culture (the "McDonaldization"), the workforce migration, global broadcasting, internet, and tourism, may help the world stir away from anarchy, with or without regional integrations. Finally, functionalism has not foreseen the weight of the environmental problems.

From a critical standpoint, the regional arrangements are already surpassed by our global problems. Critical theories tend to think globally, and reach a conclusion about the nature and value of regional integrations in function of their more general worldview.

\section{Postmodernism}

Postmodernist theories in this field have critical value, rather than theory building value. They are important not in virtue of what they say, but in virtue of what they point out to be incurrect. In this regard we can mention Ashley's 1986 criticism of IR realism, and more generally, of rationalist accounts that exogenize the actors' motives and identities. Postmodern writings pertinent to international relations aim at showing how socio-territorial identities change in time, for instance, national identities may be surpassed by either "imperial" or kinds of "regional" identities. The fluid nature of demarcating sub-national and supra-national regions invites analyses of what determines the perception of regional borders (as in Anssi Paasi), and what

\footnotetext{
${ }^{25}$ IR constructivism does not have an integration theory of its own. But it may provide arguments in support of any other. And the social constructivism of the Copenhagen School contributed to Tavares's complex security clusters proposal, which may become a better account for South-East Asia and Africa, than the economy-based functionalist account.
} 
discourses may push participants toward regional cooperation (as in Amy Skonieczny). Postmodernism is as critical of the European integration as of anything else, and no typical postmodern standpoint relative to the issue can be outlined.

\section{Feminism}

Public opinion polls tend to show a gender gap in support for the European integration. The gap is not wide, and sometimes it does not emerge as significant, but it shows up often enough to fuel beliefs that women are less happy with the EU than men. The most plausible explanation for women's less support is that they have more reasons to fear the neoclassic economic policies imposed by Brussels and the dismantling of the welfare state (which is also often attributed to the EU).

No wonder that most feminist scholarship about the EU focused on the economic, social and political position of women within the enlarged polity, maybe primarly in the employment and development sectors. Little work has been dedicated to reviewing integration theories from feminist viewpoints. Kronsell 2005 aims at filling in this gap, and makes challenging claims about the leading approaches, such as "liberal intergovernmentalism defines the place of politics as a place where women are not." ${ }^{26}$ Further, realism and intergovernmentalism assume the existence of a national interest, while "research such as MacRae's suggests that gender differences may lie behind what are perceived as consensual national interests.” Feminism is more positive about theories of multi-level governance, and about neofunctionalism's emphasis on transnational interest groups. Kronsell refers to the EU's gender mainstreaming policies and the beneficial effects of EU rules on countries that had less developed women's advancement policies. She thinks that these effects make supranationalism welcome on the feminist agenda, but suggests that Stone Sweet and Sandholtz 1997 offer the best version of theory of supranationalism, which is disputable.

More generally, feminist authors have always opposed the IR realist worldview, the masculine notions of security, and the pervasive militarization of societies (as in Tickner 1992, Enloe 2000). Regional integrations, with all their problems and failings, depart from these views.

\section{Class-Based Theories}

According to opinion polls, less educated people with lower income are less supportive of integration than the more educated and wealthier. The reasons for this phenomenon may be analogous with women's less support as compared to men's support. Yet, with regard to the respondents' party choices, a strange pattern has emerged. Until the 1990s, voters of the rightist parties were more enthusiastic about the EU. Since the 1990s, it is people on the left side of the political spectrum who offer more support to integration.

The change in party support occurred in the moment when the economic integration came to an end, and the new items on agenda fell in the direction of political unification. Though there is no elaborated Marxist theory about regional integrations and the European development, these facts can be explained with the leftist push toward embedding and domesticcating markets. The Gramscian theory of Robert Cox and Steven Gill, is geared toward showing the need for, and finding the ways to, controlling the negative effects of globalization. ${ }^{27}$

\footnotetext{
26، The focus on the unitary state is obfuscation, feminists argue, because it fails to consider the power relations inside the state and does not recognize the state's ability to exploit the resources of the nation. The concept 'state' makes the hierarchy between state and nation invisible and gender relations become irrelevant.”
}

From this perspective, regional economic integrations are valuable only if, and to the extent to which, they make possible that the market integration be accompanied by political integration. An embedded market economy frees labor, as well, not only the capital, and makes possible the application of social constraints on capital, including taxation, labor- and environmental standards.

As the best disciple of this theory, Italian communist Altiero Spinelli led a significant federalist movement since 1941 to 1986, when he died as a member of the European Parliament, which in 1984 voted 237:31 for the "Draft Treaty Establishing the European Union,” drafted by Spinelli’s Crocodile Club. ${ }^{28}$ Yet, most of the national social-democratic, socialist and communist movements find it hard to give up the familiar nationstate based interest defending schemes and think in strategies within the large European/regional arena. The nation-state focus of the Left greatly lessens pressures for political integration.

The other salient brand of Marxism-rooted thinking, that of Wallerstein (referred to as world systems theory), would probably not approve of the morality of an integration that makes the wealthy states more powerful to the detriment of the poor. Wallerstein's political intentions are better represented by the World Social Forum, than by the European integration.

Yet, the big question is that which project can be more effective in the real world to bring about peace, security, prosperity, and justice. The "peace in parts" solution works very slowly, but thus far it is the only one that managed to overcome fierce nationalisms, which, from the perspective of feminists is patriarchal, and from the perspective of Marxists, is capitalismdefending.

As a third descendent of Marxism-rooted thinking, contemporaneous representatives of the Frankfurt school work on improving and helping the functionalist project. Habermas's writings on constitutional patriotism try to bridge the gap between "thick" national identities (where citizenship is doubled by a shared culture) and "thin” European identity (where there is no shared language to foster solidarity).

Unfortunately, besides the opposition of capital to be controlled, there are two further reasons for not precipitating a European federalism as suggested by Spinelli. An enlarged polity without a sense of solidarity among members feels like an empire, may depress citizen interest and loyalty, and actually hinder the implementation of redistributive policies. Finally, experiments in multi-level governance are necessary for forging new ways of democratic self-government in large polities. It is a new political culture in formation, with proportional representation, consensus-building, involvement of the stakeholders, and of non-political participants in policy formulation, for instance.

In sum, for class-based theories, authority beyond the nation-state is a must in the globalizing world. They also believe that international and supranational formations are possible, but have not elaborated on which scenario deserves most support.

\section{Conclusion}

I started this inquiry with the observation that most accounts of the overall European integration literature delineate three main approaches: intergovernmentalism, supranationalism, and

\footnotetext{
${ }^{27}$ Closest to their concerns, it is John Ruggie's paper on the usefulness of regimes of "embedded liberalism" and Susan Strange's description of "casino capitalism" that address these problems.

${ }^{28}$ The "Draft treaty" was rejected in the Council of Ministers, but it is considered to have had an impact on negotiating the Single European Act in 1987, after decades of Eurosklerosis.
} 
federalism.

Should we really say that within the international relations field, we have other approaches?

Within IR, the proportion of "Euroskeptics," of those who do not believe that the integration is possible (or should go farther) is incommensurably higher than in 1) other disciplines, and 2) in the real life, as evidenced by opinion polls.

Among IR scholars who allow for the possibility of a European kind of "ever closer union," again,

1) the proportion of ("liberal") intergovernmentalists is comparatively very high. Functionalists and neo-functionalists are often excluded from the sphere of IR scholars, while federalism is not represented at all.

2) the proportion of those who believe that the European experience is unique and despite its success, the world remains composed of nation-states, is also very high.

Unfortunately, if functionalism is expulsed from the IR field, then we cannot claim that IR has contributed any systematic theory to explain such a highly salient phenomenon than the creation of the EU. The liberal attempts to account for it are welcome, but neither the law-based (Slaughter Burley) nor the security-based (Tavares) explanations have cohered in a mature theory yet. And they will have a hard time to get the support of liberal economists for their explanations.

\section{References}

Acharya, A. (2003). Will Asia's Past Be Its Future? International Security, 28, 149-164. doi:10.1162/016228803773100101

Adler, E., \& Barnett, M. (1998). Security communities, Cambridge University Press, Cambridge and New York. doi:10.1017/CBO9780511598661

Ashley, \& Richard, K. (1986). The Poverty of Neorealism, in Robert O. Keohane (ed). Neorealism and Its Critics, New York: Columbia University Press.

Bull, H. (1977). The Anarchical Society. London: Macmillan.

Burley, A. M., \& Walter, M. (1993). Europe Before the Court: A Political Theory of Legal Integration. International Organization 47, 1, 41-80. doi:10.1017/S0020818300004707

Buzan, B., \& Ole, W. (2003). Regions and powers: The structure of international security. Cambridge University Press, Cambridge. doi:10.1017/CBO9780511491252

Caporaso, J. (1996). The European Union and Forms of State: Westphalian, Regulatory or Post-Modern? Journal of Common Market Studies, 34, 29-52. doi:10.1111/j.1468-5965.1996.tb00559.x

Caporaso, J. A. (2005). The Possibilities of a European Identity, Brown Journal of World Affairs, 12, 65-75.

Caporaso, J., Gary, M., Andrew, M., \& Mark, A. P. (1997). Does the European Union represent an $\mathrm{n}$ of 1 ? ECSA Review, 10, 1-5.

Charillon, F. (2005). The EU as a security regime. European Foreign Affairs Review, 10, 517-533.

Cox, R. W. (1986). Social Forces, States and World Orders: Beyond International Relations Theory, in Robert O. K. (ed.). Neorealism and Its Critics, New York: Columbia University Press.

Doyle, M. W. (1986). Liberalism and World Politics Revisited, in Charles W. K. (ed.). Controversies in International Relations Theory, New York: St. Martin's Press, 1996, 83-106.

Enloe, C. (2000). Maneuvers: The International Politics of Militarizing Women's Lives. London: University of California Press.

Farrell, M., Bjorn, H., \& Luk, V. L. (eds.). (2005). Global Politics of Regionalism: Theory and Practice. Pluto Press.

Fawcett, L., \& Andrew, H. (eds.). (1995). Regionalism in World Politics: Regional Organization and International Order. Oxford/NY: Oxford University Press.

Garrett, G., \& George, T. (1996). An Institutional Critique of Intergovernmentalism. International Organization, 50, 269-99. doi:10.1017/S0020818300028563

Grieco, J. M. (1988). Anarchy and the limits of cooperation: A realist critique of the newest liberal institutionalism. International Organization, 42, 485-507. doi:10.1017/S0020818300027715

Grieco, J. M. (1995). The Maastricht treaty, economic and monetary union and the neo-realist research programme. Review of International Studies, 21, 21-40. doi:10.1017/S0260210500117504

Grieco, J. M. (1996). State interests and international rule trajecto-ries: A neo-realist interpretation of the Maastricht Treaty and Economic and Monetary Union in Europe. Security Studies, 6, 176-222.

Haas, E. B. (1964). Beyond the Nation-state. Stanford: Stanford University Press.

Haas, E. B. (1976). Turbulent fields and the theory of regional integration. International Organization, 30, 173-212. doi:10.1017/S0020818300018245

Habermas, J., \& Jacques, D. (2003). February 15, or what binds Europeans together: A plea for a common foreign policy, beginning in the core of Europe. Constellations: An International Journal of Critical \& Democratic Theory, 10, 291-298. doi:10.1111/1467-8675.00333

Harmsen, R., \& Menno, S., (eds.). (2005). Euroscepticism: Party Politics, National Identity and European Integration. (European Studies 20, Yearbook of European Studies S.). Rodopi.

Herrmann, R. K., Risse, T., \& Brewer, M. B. (eds.). (2004). Transnational Identities: Becoming European in the EU. Rowman \& Littlefield.

Hix, S. (1994). The Study of the European Community. The Challenge to Comparative Politics. West European Politics, 17, 1-30. doi:10.1080/01402389408424999

Hoffmann, S. (1964). Europe's identity crisis: Between the past and America. Daedalus, 93, 1244-1297.

Hoffmann, S. (1966). Obstinate or obsolete? The fate of the nation-state and the case of Western Europe. Daedalus, 95, 862-916.

Hoffmann, S. (1982). Reflections on the nation-state in Western Europe today. Journal of Common Market Studies, 21, 21-37. doi:10.1111/j.1468-5965.1982.tb00637.x

Hooghe, L., \& Gary, M. (2001). Multi-Level Governance and European Integration, Rowman \& Littlefield Publishers, Inc.

Huelshoff, M. G. (1994). Domestic politics and dynamic issue linkage: A reformulation of integration theory. International Studies Quarterly, 38.

Hurrell, A., \& Anand, M. (1996). Politics Like Any Other? Comparative Politics, International Relations and the Study of the EU. West European Politics, 19, 386-402. doi:10.1080/01402389608425139

Hurrell, A. (1995). Explaining the resurgence of regionalism in world politics. Review of International Studies, 21, 331-358. doi:10.1017/S0260210500117954

Hurrell, A. (2007). One World? Many Worlds? The place of regions in the study of international society, Martin Wright Lecture 2006. International Affairs, 83, 151-166.

Immanuel, M. W. (1979). The Capitalist World-Economy. Cambridge: Cambridge University Press.

Katzenstein, P. (1996). Regionalism in Comparative Perspective. ARENA Working Papers, 96, 1-43.

Keating, M. (1989). Regionalism, devolution and the state, in Garside, P. L., \& Hebbert, M. (eds.). British regionalization 1900-2000, London: Mansell.

Keohane, R., \& Stanley, H. (eds.). (1991). The New European Community: Decisionmaking and Institutional Change, Boulder, Colo. Westview.

Keohane, R. O. (1984). After Hegemony: Cooperation and Discord in the World Political Economy. Princeton, N.J: Princeton University Press.

Keohane, R. O., \& Joseph, N. (1977). Power and Interdependence. World Politics in Transition, Boston: Little, Brown and Company.

Kronsell, A. (2005). Gender, power and European integration theory, Journal of European Public Policy, 12, 1022-1040. doi:10.1080/13501760500270703

Majone, G. (2001). Regulatory Legitimacy in the United States and the European Union, in Kalypso, N., \& Robert, H. (eds.). The Federal Vision: Legitimacy and Levels of Governance in the US and the European Union, Oxford University Press.

Mansfield, E. D., \& Helen, V. M. (1999). The New Wave of Regionalism. International Organization, 53, 589-627.

Marks, G., Liesbet, H., \& Kermit, B. (1996). European Integration from the 1980s: State-Centric v. Multi-Level Governance, Journal of Com- 
mon Market Studies, 34, 341-378. doi:10.1111/j.1468-5965.1996.tb00577.x

Mattli, W. (1999). Explaining regional integration outcomes. Journal of European Public Policy, 6, 1-27. doi:10.1080/135017699343775

Mattli, W. (2000). Sovereignty bargains in regional integration. International Studies Review, 2, 149-180. doi:10.1111/1521-9488.00208

Mazey, S. (2002). Gender mainstreaming strategies in the EU: Delivering on an agenda? Feminist Legal Studies, 10, 227-240.

doi:10.1023/A:1021223828355

McLaren, L. (2006). Identity, Interests and Attitudes to European Integration, (Palgrave studies in European Union Politics), Palgrave Macmillan.

Mearsheimer, J. (1990). Back to the future: Instability in Europe after the Cold War. International Organization, 15.

Milner, H. (1992). International theories of cooperation among nations: Strengths and weaknesses. World Politics, 44.

Mitrany, D. (1933). The Progress of International Government. New Haven.

Moravcsik, A. (1991). Negotiating the Single European Act: National interests and conventional statecraft in the European Community. International Organization, 45, 19-56. doi:10.1017/S0020818300001387

Moravcsik, A. (1993). Preferences and power in the European Community: A liberal intergovernmentalist approach. Journal of Common Market Studies, 31, 473-524. doi:10.1111/j.1468-5965.1993.tb00477.x

Moravcsik, A. (1997). Taking preferences seriously: A liberal theory of international politics. International Organization, 51, 513-53. doi:10.1162/002081897550447

Moravcsik, A. (1998). The Choice for Europe: Social Purpose and State Power from Messina to Maastricht. (Cornell Studies in Political Economy), Cornell University Press.

Moravcsik, A. (1999). Is something rotten in the state of Denmark? Constructivism and European integration. Journal of European Public Policy, 6, 669-681. doi:10.1080/135017699343531

Moravcsik, A., \& Kalypso, N. (1999). Explaining the treaty of Amsterdam: Interests, influence, institutions. Journal of Common Market Studies, 37, 59. doi:10.1111/1468-5965.00150

Nye, J. S. (1968). Comparative regional integration: Concept and measurement. International Organization, 22, 855-880. doi:10.1017/S0020818300013837

Nye, J. S. (1971). Peace in parts: Integration and conflict in regional organization. Boston: Little Brown and Company.

O’Neill, M. (1996). The Politics of European Integration: A Reader. Routledge. doi:10.4324/9780203428320

Paasi, A. (2002). Regional transformation in the European context: Notes on regions, boundaries and identity. Space and Polity, 6, 197201. doi:10.1080/1356257022000003626

Puchala, D. J. (1972). Of blind men, elephants and international integration. Journal of Common Market Studies, 10, 267-284. doi:10.1111/j.1468-5965.1972.tb00903.x

Risse, T. (2005). Neofunctionalism, European identity, and the puzzles of European integration. Journal of European Public Policy, 12, 291309. doi:10.1080/13501760500044033

Risse, T., \& Antje, W. (1999). "Something rotten" and the social construction of social constructivism: A comment on comments. Journal of European Public Policy, 6, 775-782. doi:10.1080/135017699343379

Rosamond, B. (2000). Theories of European Integration. (The European Union), Palgrave Macmillan.
Ruggie, J. G., Katzenstein, P. J., Keohane, R.O., \& Schmitter, P. C. (2005). Transformations in world politics: The intellectual contributions of Ernst B. Haas. Annual Review of Political Science, 8.

Ruggie, J. (1983). International regimes, transactions, and change: Embedded liberalism in the postwar economic order. Stephen D. K. (ed.). International Regimes.

Russett, B., \& John, O. (2001). Triangulating peace: Democracy, interdependence, and international organizations. Norton, W. W. Company, Inc.

Sandholtz, W., \& John, Z. (1989). 1992: Recasting the European bargain. World Politics, 42, 95-128. doi:10.2307/2010572

Skonieczny, A. (2001). Constructing NAFTA: Myth, representation, and the discursive construction of U.S. foreign policy. International Studies Quarterly, 45, 433-454. doi:10.1111/0020-8833.00208

Slaughter, B., \& Anne, M. (1993). International Law and International Relations Theory: A dual agenda. American Journal of International Law, 87, 35.

Tavares, R. (2008). Understanding regional peace and security: A framework for analysis. Contemporary Politics, 14, 107-127. doi:10.1111/0020-8833.00208

Taylor, P. (1983). The Limits of European Integration. London and Canberra: Croom Helm.

Tickner, A. (1992). Gender in International Relations: Feminist Perspectives on Achieving International Security. New York: Columbia University Press.

Tsebelis, G., \& Geoffrey, G. (2001). The institutional foundations of intergovernmentalism and supranationalism in the European Union. International Organization, 55, 357-390. doi:10.1162/00208180151140603

Waever, O. (1995). Identity, integration and security: Solving the sovereignty puzzle in E.U. Studies. Journal of International Affairs, 48, 389-431.

Wallace, H., James, A. C., Fritz, W. S., \& Andrew, M. (1999). Review section symposium: The choice for Europe: Social purpose and state power from Messina to Maastricht. Journal of European Public Policy, 6, 155-179. doi:10.1080/135017699343856

Walt, S. M. (1997). Why alliances endure or collapse. Survival, 39 156-179. doi:10.1080/00396339708442901

Waltz, K. (1959). Man, the State, and War. NY: Columbia University Press.

Waltz, K. (1979). Theory of International Relations. NY: Random House.

Weiler, J. H. H. (1999). The Constitution of Europe: Do the New Clothes Have an Emperor? And Other Essays on European Integration. Cambridge: Cambridge University Press.

Wendt, A. (1994). Collective identity formation and the international state. American Political Science Review, 88, 384-396. doi:10.2307/2944711

Wendt, A. (1999). Social Theory of International Politics. NY: Cambridge University Press.

Wiener, A., \& Diez, T. (eds.). (2004). European Integration Theory: Past, Present and Future. Oxford: Oxford University Press.

Wincott, D. (1995). Institutional interaction and European integration: Towards an everyday critique of Liberal intergovernmentalism. Journal of Common Market Studies, 33, 597-609. doi:10.1111/j.1468-5965.1995.tb00553.x

Zürn, M., \& Jeffrey, T. C. (2005). Getting socialized to build bridges: Constructivism and rationalism, Europe and the Nation-State. International Organization, 59, 1045-1079. 